\title{
Pre-Service English Teachers' Beliefs about Teaching and Learning English in Microteaching Guided by an Expert Secondary English Teacher
}

\author{
Siti Aimah ${ }^{1}$, Dwi Rukmini ${ }^{2}$, Mursid Saleh ${ }^{3}$, Dwi Anggani Linggar Bharati ${ }^{4}$ \\ $\left\{\underline{\text { siti.aimah@unimus.ac.id }}{ }^{1}\right.$, wiwidwirukmini@yahoo.com ${ }^{2}$, mursids@ @otmail.com $^{3}$, \\ dwi anggani@yahoo.com ${ }^{4}$ \} \\ Universitas Negeri Semarang ${ }^{1234}$, Jl. Kelud Utara III, Semarang 50237 Indonesia' ${ }^{1234}$
}

\begin{abstract}
Beliefs play an important role in determining the success of teaching and learning in the classroom. Teachers must not only consider the subject matter taught but also the other components which are also very fundamental to build the quality of teaching and learning. This study aims at identifying eleven pre-service English teachers' beliefs about teaching and learning English in microteaching guided by an expert secondary English teacher at Universitas Muhammadiyah Semarang, Indonesia. A case study was employed in which questionnaire and interview were administered to collect the data from the participants. The result reveals that there are six categories of beliefs about teaching and learning English determining the success of carrying out the instructional process. They are English use-oriented beliefs, teacher role-oriented beliefs, student role-oriented beliefs, teaching components-oriented beliefs, curriculum oriented-beliefs, and curriculum and course book content relationship-oriented beliefs. Those categories could not be separated and are closely related to each other to implement the teaching and learning process. Therefore, pre-service English teachers need to possess themselves with the knowledge of professional and pedagogy to help them in designing meaningful learning to the students.
\end{abstract}

Keywords: beliefs, microteaching, pre-service English teachers, teaching and learning English

\section{Introduction}

In implementing the teaching and learning process in the classroom, what is required for pre-service teachers is to optimize their educational experience to transfer their knowledge to students. Their experience influences their beliefs and actions of teaching [1]. In this case, preservice teachers commonly use their educational experiences to help them in interpreting the input provided in the teacher education program [2], [3]. It is reasonable since pre-service teachers do not have their own class of teaching. They require knowledge acquired from their educational experiences to be transferred to students.

Besides knowledge and practice, beliefs also help them much in determining how to succeed in implementing the instructional practice. There are three primary points required for teachers in implementing and succeeding their instructional practices: knowledge, beliefs, and practice [4]. Those are very fundamental to build the quality of teaching and learning of language. 
Beliefs are regarded as an important part in the process of teaching and learning [3], [2], [5], [6], [7], [8] because pre-service teachers must focus not only on the subject matter but also on the other components which also have important roles in the process of teaching and learning.

However, in the microteaching class, pre-service English teachers commonly only focused on the content taught to the students. Most of them argued that mastery of the content is the most important thing in teaching among others. If they did not master the content, they could not explain the content, and their students would ignore them during the class. They also said that preparing teaching administration was a prerequisite to do in which they had to determine the subject matter taught to the students. Unfortunately, some of them ignored the other components that were also required in the teaching and learning process. One of the examples is the use of English in the classroom. Teaching English as a foreign language was one of the obstacles faced by most of them in which the students communicated using their mother tongue, Bahasa Indonesia. Their difficulty in understanding English made them prefer using Bahasa Indonesia to using English in explaining the material. Consequently, the aim of teaching English could not be achieved well.

Various studies have investigated pre-service teachers' beliefs in microteaching class [9], [10], [11], [7], [12], the changes of beliefs of pre-service teachers [13], [14], [15], [16], and beliefs about teaching and learning focusing on the subject matter [17].

By referring to the focus of pre-service English teachers' beliefs in microteaching class, this study aims at identifying pre-service English teachers' beliefs about teaching and learning English in the class of microteaching guided by an expert secondary English teacher. The class of microteaching which is commonly guided by a lecturer, in this case, is guided only by an expert secondary English teacher. The expert secondary English teacher is chosen based on the length of experiences of teaching (more than 15 years), the expertise in creating meaningful learning, being a national instructor of the 2013 curriculum, and the experiences of giving training to Indonesian teachers.

\section{Methods}

A case study was employed in this study in which eleven pre-service English teachers joined in the class of microteaching guided by an expert secondary English teacher. All of them were well-informed about the aim of this study.

To investigate the beliefs of eleven pre-service English teachers about teaching and learning English, 30 Likert-scale items were divided into six different categories which ranged from 1 (strongly disagree) to 4 (strongly agree). The questionnaire was adapted and modified from [18], [19], [20] idea focusing not only on the subject matter but also on the other important components of teaching and learning English such as the use of English in EFL lessons, the teacher role, the student role, the teaching components (material and resources, EFL activities, learning aims, contents, teaching methodologies, assessment), the role of curriculum, and the relationship between the curriculum and the course book content.

The questionnaire was firstly administered to them at the beginning of the class of microteaching guided by an expert secondary English teacher. An interview was also employed to them individually after being distributed questionnaire. To get more in-depth and more accurate information, the interview to the participants was delivered in Bahasa Indonesia. 


\section{Results and Discussion}

To answer the aim of this study, there are six categories and five subcategories presented and discussed at this point in which those are adjusted with the needs of teaching for EFL learners. Those categories are English use-oriented beliefs, teacher role-oriented beliefs, student role-oriented beliefs, teaching components-oriented beliefs, curriculum-oriented beliefs, and curriculum and course book content relationship-oriented beliefs.

\subsection{English Use-Oriented Beliefs}

In teaching English, what is required by teachers is the use of English in the classroom. It is because the goal of learning English for EFL learners is to actively communicate with others. Therefore, the English teacher should trigger the students to use English in the classroom. The results of English use-oriented beliefs in the classroom are demonstrated in Table 1.

Table 1. The Mean Scores of English Use-Oriented Beliefs

\begin{tabular}{|c|c|c|c|}
\hline & $\begin{array}{l}\text { Questionnaire Statements } \\
\text { (English Use-Oriented Beliefs) }\end{array}$ & Mean Scores & Category \\
\hline QS_1 & $\begin{array}{l}\text { The use of English in the classroom is very crucial } \\
\text { and beneficial to students in learning language. }\end{array}$ & 3.5 & Very good \\
\hline QS_2 & $\begin{array}{l}\text { The use of English in the classroom influences } \\
\text { students to speak English. }\end{array}$ & 3.2 & Very good \\
\hline QS_3 & $\begin{array}{l}\text { The use of English should be the main language used } \\
\text { in the classroom. }\end{array}$ & 3 & Good \\
\hline QS_4 & $\begin{array}{l}\text { The teacher needs to use English in explaining the } \\
\text { content to students. }\end{array}$ & 2.8 & Good \\
\hline QS_5 & $\begin{array}{l}\text { Interaction between the teacher and students in } \\
\text { English is an important factor in the process of } \\
\text { teaching and learning language. }\end{array}$ & 3.5 & Very good \\
\hline
\end{tabular}

By referring to the 2013 curriculum, the main purpose of learning English for the secondary school students is to be able to communicate to others either in written or spoken forms. Therefore, English is very crucial to learn, especially for secondary school students. Teaching English as a foreign language becomes a challenging activity for the English teachers in Indonesia because the majority of the students do not access English in their life. T this point, the main problem of learning English for EFL students is they do not access English directly such as using English as a means of communication, reading English magazines or newspapers for five to ten minutes in a day, watching English movie, etc. [21].

Therefore, the English teachers should maximize the use of English in the classroom. Students need to be exposed to use English during English lesson [19]. Dealing with this point, most pre-service English teachers strongly agree that the use of English in the classroom is very crucial. It is proven with the result of the first subcategory in which the mean is 3.5 (very good). If the teachers use English optimally in the classroom, thus, the students will also be triggered to speak English (3.2).

However, dealing with the use of English in the classroom, not all pre-service English teachers strongly agree that English is the main language to use. The mean obtained for this point is only 3 (good). Based on the result of the interview, some pre-service English teachers mention that the use of English for classroom interaction is very good to influence the students to speak English. At this point, they affirm, based on their own experience in practicing their 
teaching in secondary schools, the use of English for teaching foreign learners is not easy. Many students do not understand what they are talking about in English. Hence, they have to use codemixing. It aims to help the students to understand the content taught.

The mean of using English in explaining the content to the students is 2.8 (good). It shows that pre-service English teachers need some efforts to teach English as a foreign language. The students' tendency to use Bahasa Indonesia rather than English in the classroom influences their ability in mastering English. Pre-service English teachers explain that it is not easy to teach foreign learners who tend to use their mother tongue to speak. They further explain that the significant differences between English and Bahasa Indonesia are on different writing and pronunciation in which both become a main problem and a challenging activity for teaching English as a foreign language. The difference between their mother tongue and English in both orthography and directionality is further mentioned as the problem mostly faced by foreign learners [22].

Mostly, the students do not understand the material taught by the teacher if they only use English. Consequently, they have to re-teach the students by using Bahasa Indonesia in the next meeting. This condition is undoubtedly not effective since there are many materials that they have to teach to the students. However, the time allotment is limited.

Meanwhile, pre-service English teachers strongly agree that the interaction between teacher and students in English is an important factor in the process of teaching and learning. It is shown with the result obtained of 3.5 (very good). They admit that teaching English is a complex activity. It requires them to be creative in designing challenging activities which can trigger the students to use English optimally in the classroom.

When they interact with their students in English, their students will have an effort to use English as well. Thus, English teachers should always stimulate their students to use English in the process of teaching and learning. It will help them in improving their ability to speak since environment, i.e. an English classroom is an important factor to determine the success of using the target language.

\subsection{Teacher Role-Oriented Beliefs}

In the process of teaching and learning English language, the English teacher has an important role in determining the success of teaching and learning. The mean scores of teacher role-oriented beliefs in teaching and learning process are enumerated in Table 2.

Table 2. The Mean Scores of Teacher Role-Oriented Beliefs

\begin{tabular}{|c|c|c|c|}
\hline & $\begin{array}{l}\text { Questionnaire Statements } \\
\text { (Teacher Role-Oriented Beliefs) }\end{array}$ & Mean Scores & Category \\
\hline QS_6 & $\begin{array}{l}\text { The teacher has an important role in teaching and } \\
\text { learning. }\end{array}$ & 3.6 & Very good \\
\hline QS_7 & $\begin{array}{l}\text { The teacher is the main agent in the teaching and } \\
\text { learning process. }\end{array}$ & 3 & Good \\
\hline QS_8 & $\begin{array}{l}\text { The teacher is a role model for students in the use of } \\
\text { English. }\end{array}$ & 3.8 & Very good \\
\hline QS_9 & $\begin{array}{l}\text { The teacher needs to use the appropriate strategies to } \\
\text { trigger students to speak English. }\end{array}$ & 3.4 & Very good \\
\hline QS_10 & $\begin{array}{l}\text { The teacher needs to encourage students to develop } \\
\text { their language skills. }\end{array}$ & 3.5 & Very good \\
\hline
\end{tabular}


Based on Table 3.2, it shows that the teacher has an important role in the teaching and learning process. It is proven with the mean obtained of 3.6 with the category of very good. Preservice English teachers agree that the teacher is the main agent in the classroom, even though there are other factors that influence the success of teaching and learning such as students, learning resources, media, methods of learning, and curriculum. Based on their explanation, the role of the teacher as the main agent in the classroom means that the English teachers are determinants of whether or not the teaching and learning process is successful. If they can design their meaningful learning to the students, the students may learn actively through the activities designed, vice versa. Some pre-service English teachers further explain that the teacher is not the only one determining the success of teaching and learning. There are many other factors whose roles are as important as teacher role. Those are related to each other in the instructional process. Thus, at this point, the score which is obtained is 3 with a good category.

Some pre-service English teachers say that in learning English, it is difficult to learn without being guided by the English teacher. Instructions given by an English teacher determine whether or not the students can be autonomous, active, and responsible for what they learn [23], [24]. This condition triggers pre-service English teachers to assume that their competence in English influences their students to speak English (3.8). They also say when the English teachers optimize the use of English in the classroom, their students will try to respond to them in English. Otherwise, if the teaching and learning process is delivered in Bahasa Indonesia, their students tend to use Bahasa Indonesia as well during the process of teaching and learning. Thus, English teachers should improve their competence not only in pedagogical aspect but also in the professional one.

To trigger the students to speak, what is required by English teachers is to use all available teaching strategies which are suitable to students' needs and characteristics. The importance of having knowledge of teaching strategies by the teacher is shown with the result obtained of 3.4 with a very good category. Pre-service English teachers explain that teaching strategies included in pedagogical knowledge is very important for English teachers to carry out the instructional process. It will help them to design their class in which the students will be involved actively in the classroom through some challenging activities. They say that good English teachers will not let their students passive in the classroom. They will trigger their students to involve in the teaching and learning process actively.

Meanwhile, dealing with the importance of the teacher encourages the students to develop their language skills is shown with the result of 3.5 with a very good category. In this case, preservice English teachers explain that English teachers should focus their attention on their students' motivation to learn English. Students' motivation determines the way the English teachers create effective learning in the classroom. Therefore, English teachers should motivate their students to use English in the classroom [25]. It is also important for them to consider students' emotional inhibitions such as anxiety, shyness, and fear of failure. Therefore, the English teachers should create a friendly environment in order the reluctant students become relax in learning and using English.

\subsection{Student Role-Oriented Beliefs}

A student also has an important role in the teaching and learning process in the classroom. Without a teacher, it is impossible to carry out the instructional process. Otherwise, without the student, the teacher could not teach in the classroom as well. The importance of student role in the classroom can be seen in Table 3 . 
Table 3. The Mean Scores of Student Role-Oriented Beliefs

\begin{tabular}{llcc}
\hline & $\begin{array}{l}\text { Questionnaire Statements } \\
\text { (Student Role-Oriented Beliefs) }\end{array}$ & Mean Scores & Category \\
\hline QS_11 & $\begin{array}{l}\text { The role of the teacher as important as the role of student } \\
\text { QS_12 }\end{array}$ & 3.3 & Very good \\
QS_13 & $\begin{array}{l}\text { A students need to be motivated in learning language. } \\
\text { learning. }\end{array}$ & 3.5 & $\begin{array}{l}\text { Very good } \\
\text { Very good }\end{array}$ \\
QS_14 & $\begin{array}{l}\text { The teacher needs to monitor students' understanding } \\
\text { during instruction. }\end{array}$ & 3.4 & Very good \\
QS_15 & $\begin{array}{l}\text { Students need to be active to develop their } \\
\text { communication in English with their peers and teacher. }\end{array}$ & 3.4 & Very good \\
\hline
\end{tabular}

Table 3.3 shows that the mean score of student role in teaching and learning English as important as teacher role is 3.3 (very good). Pre-service English teachers also strongly agree that student-centered learning must be optimized by English teachers in order the learning objective could be achieved. Their agreement is shown with the result obtained is 3.3 . It is in line with Tudor [26] what must be emphasized by English teachers to create active learning is by focusing on student-centered learning.

Pre-service English teachers also explain that students need to be motivated by English teachers in learning English. Without being given motivation, the students will not improve their achievement of learning. The importance of motivation from the English teachers is shown with the result obtained of 3.5 with a very good category. Furthermore, they explain that motivated students will have good confidence in using English in a classroom and improving their achievement of learning. It means that motivation and the use of learning strategy affect the improvement of student learning outcomes [27].

However, pre-service English teachers also remind the English teachers to evaluate students' understanding during the English lesson. It is proven that the result obtained is 3.4 with a good category. It is understandable since English has different ways in term of writing and pronouncing. They explain that to teach English as a foreign language, the English teachers must be aware of the students' background knowledge. They have to evaluate whether or not the students understand what they are talking about during the instruction. Pre-service English teachers suggest the English teachers to use bilingual, i.e. English and Bahasa Indonesia to make sure that the material taught could be understood well by students.

The use of English, which is still limited in the classroom must be optimized out of class as well. Pre-service English teachers say that the English teachers must be consistent in using English as their communication with their students in the English classroom (3.4). They also explain that some students are commonly fear of making mistakes in grammar, pronunciation, and lack of vocabulary. In facing those students, the English teachers need to motivate and trigger them to more practice in using English with either their English teachers or their friends. Reinforcement, at this point, is required by the students to learn from the mistakes that they have made.

\subsection{Teaching Components-Oriented Beliefs}

Besides the role of teacher and student in the language classroom, teaching components are also required in the instructional process such as resources, learning objectives, teaching methodologies, and assessment.

Learning objective is the first step to do by the teachers in preparing their teaching. It includes the activities of learning, the chosen materials, the use of learning 
strategies/methodologies, the media/resources, and the assessment. The importance of learning objective in the process of teaching is proven with the mean of 3.2. Pre-service English teachers explain that in some cases, some teachers ignore telling the students the learning objective. The students do not know what the purpose of learning the content is. Consequently, at the end of the teaching, the learning objective could not be achieved.

When the teachers can formulate the learning objective, pre-service English teachers remind that they should be able to adapt the content/material with the students' needs, knowledge, and interest. The use of different materials/resources could be optimized by adapting and modifying them based on students' needs [28]. What needs to do by the teachers is simplifying the material taught to the students. Dealing with this point the mean of 3.2 is obtained with a very good category. In detail, the results of teaching components-oriented beliefs are depicted in Table 4.

Table 4. The Mean Scores of Teaching Components-Oriented Beliefs

\begin{tabular}{llcll}
\hline & $\begin{array}{l}\text { Questionnaire Statements } \\
\text { (Teaching Components-Oriented Beliefs) }\end{array}$ & Mean Scores & Category \\
\hline QS_16 & $\begin{array}{l}\text { The teacher needs to use different kinds of materials and } \\
\text { resources in his/her lesson. }\end{array}$ & 3.3 & Very good \\
QS_17 & $\begin{array}{l}\text { The teacher needs to adapt the content of the lesson } \\
\text { according to students' needs, knowledge, and interest. } \\
\text { The teacher needs to explicitly state the objective of } \\
\text { QS_18 }\end{array}$ & 3.2 & Very good \\
QS_19 & $\begin{array}{l}\text { The teacher needs to use different kinds of teaching } \\
\text { methodologies. } \\
\text { The teacher needs to adapt the assessment instruments to } \\
\text { students' needs and the learning objective. }\end{array}$ & 3.5 & Very good \\
QS_20
\end{tabular}

Most pre-service English teachers affirm that the use of different kinds of teaching methodologies is to avoid students' boredom. It is proven that the mean obtained is 3.5 with a very good category. They agree that English teachers need to equip themselves with the knowledge of pedagogy that is required to carry out the instructional processes. It is because they need not only transfer their knowledge to students but also how to transfer it into more understandable to the students. The teachers should be creative in designing their lesson and involving their students actively in the classroom.

Besides teaching methodologies, it is also important for English teachers to use different kinds of materials to support their teaching. Dealing with this point, the mean of using different types of materials/resources is 3.3. Pre-service English teachers say that the use of various materials/resources enable the teachers to teach the material contextually and accurately to the students. Through contextual learning, the students will be easier in understanding the content taught by their teachers.

Pre-service English teachers also agree that the assessment instruments must be adjusted with students' needs and learning objective. The mean of it is 3.1 (very good). Assessment is used to measure whether or not the learning objective is achieved. Referring to the 2013 curriculum, the assessment includes the aspects of attitude, knowledge, and skill. Those aspects should be measured to have information about students' behavior, students' mastery of the material, and students' ability in implementing certain skills. Therefore, teaching components are integrated in the process of teaching and learning. 


\subsection{Curriculum-Oriented Beliefs}

The successful of teaching and learning process lies on the effective curriculum implemented by the teachers [29]. Before conducting the teaching and learning process, what is required by English teachers is comprehending the curriculum. The teachers need to know the curriculum implemented and adjust their lesson with the students' needs. Without understanding curriculum, they may not limit the scope of the lesson, link the relevant material with the competence, choose the appropriate material and integrate it with the others, determine the learning strategies, and evaluate students' learning. The importance of comprehending curriculum is shown with the result obtained is 3.1 .

Through comprehending the curriculum, pre-service English teachers affirm that it will be easier for the teachers to formulate the learning objective (3.2). Their comprehension of formulating the learning objective will influence the way they are teaching. It includes how to choose the appropriate strategies, media, and resources, simplify the material, and evaluate students' understanding in accordance with students' needs, interest, and background knowledge in which those are included in a lesson plan that they have to design. The needs of designing a lesson plan are accommodated through the mean obtained of 3.4 with a very good category.

Table 5. The Mean Scores of Curriculum-Oriented Beliefs

\begin{tabular}{|c|c|c|c|}
\hline & $\begin{array}{l}\text { Questionnaire Statements } \\
\text { (Curriculum-Oriented Beliefs) }\end{array}$ & Mean Scores & Category \\
\hline QS_21 & $\begin{array}{l}\text { The teacher needs to comprehend the curriculum and } \\
\text { adapt his/her lessons with the curriculum. }\end{array}$ & 3.1 & Very good \\
\hline QS_22 & $\begin{array}{l}\text { The teacher needs to formulate the objective of learning } \\
\text { appropriately. }\end{array}$ & 3.2 & Very good \\
\hline QS_23 & $\begin{array}{l}\text { The teacher needs to design his/her lesson plans } \\
\text { adjusted with students' needs, interest, and background } \\
\text { knowledge. }\end{array}$ & 3.4 & Very good \\
\hline QS_24 & $\begin{array}{l}\text { The teacher needs to provide a lot of varied activities of } \\
\text { learning stimulating students to be active. }\end{array}$ & 3.4 & Very good \\
\hline QS_25 & $\begin{array}{l}\text { The teacher needs to assess students' learning by } \\
\text { considering all aspects (cognitive, affective, and } \\
\text { psychomotor). }\end{array}$ & 3.4 & Very good \\
\hline
\end{tabular}

Pre-service English teachers also agree that English teachers should provide a lot of varied activities of learning stimulating students to be active (3.4). The challenging activities which are provided by the teachers also aim to optimize the use of English in a classroom. To trigger EFL students to speak in English, it can be used through games [28]. It is because games, for the students, look more appealing and accessible. Games avoid students' boredom and help students to complete the lesson through interesting activities.

During the process of teaching and learning, what is emphasized by pre-service English teachers, is by assessing the students in the aspects of cognitive, affective, and psychomotor in which the mean obtained is 3.4. Those domains build a positive correlation, which is associated with each other. The affective aspect focusing on students' attitudes and interest in learning will be inclined to pursue their learning in the future [30]. Students with high attitude will have high cognitive-psychomotor learning outcomes [31]. 


\subsection{Curriculum and Course Book Content Relationship-Oriented Beliefs}

Most pre-service English teachers agree that there is a relationship between curriculum and course book content. It can be seen from the results presented in Table 6 .

Table 6. The Mean Scores of Curriculum and Course Book Content Relationship-Oriented Beliefs

\begin{tabular}{|c|c|c|c|}
\hline & $\begin{array}{l}\text { Questionnaire Statements } \\
\text { (Curriculum and Course Book Relationship-Oriented } \\
\text { Beliefs) }\end{array}$ & Mean Scores & Category \\
\hline QS_26 & $\begin{array}{l}\text { A curriculum is a model for a teacher to develop his/he1 } \\
\text { lessons. }\end{array}$ & 3.4 & Very good \\
\hline QS_27 & $\begin{array}{l}\text { There is a relationship between the curriculum and the } \\
\text { contents in the student textbook. }\end{array}$ & 3.2 & Very good \\
\hline QS_28 & $\begin{array}{l}\text { The teacher needs to relate the contents with students' } \\
\text { language needs }\end{array}$ & 3.4 & Very good \\
\hline QS_29 & $\begin{array}{l}\text { The teacher needs to re-organize what is included in the } \\
\text { textbook and to create new supporting materials. }\end{array}$ & 3.4 & Very good \\
\hline QS_30 & $\begin{array}{l}\text { The teacher needs to understand time allocation, tools, and } \\
\text { resources required to present the contents in student } \\
\text { textbook. }\end{array}$ & 3.1 & Very good \\
\hline
\end{tabular}

Based on Table 6, pre-service English teachers highlight that curriculum is a model/guidance for teachers to develop their lessons in which the mean got is 3.4. Through the curriculum, the activities of teaching and learning are more systematic. The contents taught to the students are related to the aim of learning as well. However, they affirm that they have to make improvisation of teaching to be more contextual.

Some pre-service English teachers affirm that curriculum is a guide for English teachers in using textbook. It is shown with the mean obtained is 3.2. They believe that a textbook used by the students aims to achieve the learning objectives. They also remind that English teachers should relate the content with students' language needs (3.4). In this case, the teachers should understand what is needed by their students in learning. Therefore, it is important for teachers to re-organize their teaching to be more effective (3.4). By re-organizing their teaching, they will learn how to manage the time, utilize the use of tools and resources to present the contents from students' textbook (3.1).

\section{Conclusion}

From those six categories, it can be seen the relationship each element that influences and affects the process of teaching and learning English in the classroom. Those integrated elements are strengthened and proven with pre-service English teachers beliefs about teaching and learning English, which is considered very good (3.3). It also proves that subject matter is not the only one which is important to be prepared by pre-service English teachers in carrying out the instructional process. It is contradiction with the result of [17] in which the subject matter is the main focus in the process of teaching and learning.

The use of English in EFL lesson is basically determined by the curriculum in which it guides English teachers in implementing the instructional process. Thus, it requires English teachers whose roles are as counselors, facilitators, instructors, mediators, and evaluators. It also requires the students who are motivated to learn and actively involved in teaching and learning 
process. In implementing the teaching and learning process, it must be supported with the teaching methodologies chosen by the teachers, the use of appropriate media and resources adjusted with students' needs and interest. The English teachers, at this point must understand the learning objectives, what competence that students must be achieved, and be able to adapt and modify the contents taught to the students. Therefore, teaching methodologies have important roles in determining whether or not the process of teaching and learning is successful since it determines the way the teachers transfer their knowledge into understandable one to the students. By understanding the learning objectives, the teachers are also able to determine and relate what assessment that must be given to the students.

Even though pre-service English teachers have good beliefs about teaching and the learning English language, there are some points that are emphasized by them in carrying out the instructional process. First, the use of English in EFL lesson should not be used all the time during the lesson. It is because English teachers should consider the students' background knowledge in which English is not their first or second language. There are many students who do not understand their teachers' explanation in English. Therefore, the teachers should use code-mixing to help them in understanding the material taught by the teachers. However, preservice English teachers also remind the English teachers to use and optimize the use of classroom language in order their students are familiar with the instructions in English. The English teachers should also motivate and trigger the students to use English to interact with their teachers and their peers.

Second, as English teachers, pre-service English teachers affirm that they are models for their students to perform. Therefore, to achieve the goal of teaching English, they need to share with them how to communicate in English well. If they never use English to communicate with, the goal of learning English will not be achieved optimally.

Third, EFL students must be involved actively in the classroom through challenging activities designed by English teachers. It is because their role in teaching and learning process is as crucial as the other components [18]. Therefore, student-centered learning is a good way to accommodate their students in teaching and learning process.

Fourth, pre-service English teachers believe that learning pedagogy is necessary for them to be English teachers. The appropriateness in choosing teaching methodologies, adapting and modifying the contents, and determining the assessment has important roles in succeeding the teaching and learning process in the classroom.

Fifth, the success of teaching English is also determined by the language curriculum implemented by English teachers. Pre-service English teachers admit that to implement the curriculum, it needs a process to understand it well. They need to understand how to formulate the objective of learning in which it will influence them to design their teaching and learning process, including the appropriateness in choosing the teaching components.

Sixth, pre-service English teachers remind the English teachers not to rely on the use of a course book as the only source used. However, in utilizing the use of course book, they should adapt and modify the contents from the course book and make improvisation for their teaching to be more effective.

The success of carrying out the instructional process for pre-service English teachers could not be separated from the process of learning meaningful lessons in the class of microteaching guided by an expert secondary English teacher. The exemplary lessons shared with them give a clear description of how to teach their students into more understandable one started from the very early stages that they have to do [32]. The illustrations/examples which are given also help the students in understanding the content. Therefore, pre-service English teachers should always link their beliefs with their knowledge and practice to conduct teaching and learning process in 
the classroom. Knowledge required by the English teachers is not only about mastering English or the contents taught. However, pedagogical knowledge plays an important role in helping the teachers in preparing the scenario of learning. What they believe about teaching and learning English will also affect them in carrying out the instructional processes in the classroom.

Acknowledgment. The authors would like to thank Ministry of Research, Technology, and Higher Education (Ristekdikti) providing financial support for this research. 


\section{References}

[1] Thomas, C. N.: Considering the impact of preservice teacher beliefs on future practice. Intervention in School and Clinic, Vol. 49, No. 4, pp. 230-236 (2013)

[2] Kagan, D. M.: Implication of research on teacher belief. Educational Psychologist, Vol. 27, No. 1, pp. 65-90 (1992)

[3] Borg, S.: Teacher cognition in language teaching: a review of research on what language teachers think, know, believe, and do. Language Teaching, Vol. 36, pp. 81-109 (2003)

[4] Putman, R. T., \& Borko, H.: Teacher learning: implications of new views of cognition. in b. j. biddle, et al. (eds.) International handbook of teachers and teaching, pp. 1223-1224. Netherlands: Kluwer Academic (1997)

[5] Othman, J., \& Kiely, R.: Preservice teachers' beliefs and practices in teaching English to young learners. Indonesian Journal of Applied Linguistics, Vol. 6, No. 1, pp. 50-59 (2016)

[6] Kuzborska, I.: Links between teachers' beliefs and practices and research on reading. Reading in a Foreign Language, Vol. 23, No. 1, pp. 102-128 (2011)

[7] Levin, T., \& Wadmany, R.: Changes in educational beliefs and classroom practices of teachers and students in rich technology-based classrooms. Technology, Pedagogy, and Education, Vol. 14, No. 3, pp. 281-308 (2005)

[9] Abasifar, S. \& Fotovatnia, Z.: Impact of teacher training course on Iranian EFL teachers' beliefs. International Journal of Foreign Language Teaching \& Research, Vol. 3, No. 9, pp. 63-75 (2015)

[10] Cebeci, N.: Prospective teachers' beliefs about microteaching. ELT Research Journal, Vol. 5, No. 1, pp. 60-71 (2016)

[11] Cinici, A.: Pre-Service teachers' science teaching self-efficacy beliefs: the influence of a collaborative peer microteaching program. Mentoring \& Tutoring: Partnership in Learning, Vol. 24, No. 3, pp. 228-249 (2016)

[12] Ünlü, M.: Effect of microteaching practices with concrete models on pre-service mathematics teachers' self-efficacy beliefs about using concrete models. Universal Journal of Educational Research, Vol. 6, No. 1, pp. 68-82 (2018)

[13] Clark-Goff, K.: Exploring change in preservice teachers' beliefs about English language learning and teaching. Dissertation, Texas A\&M University (2008)

[14] Clark-Goff, K. \& Eslami, Z.: Exploring change in preservice teachers' beliefs about English language learning and teaching. Iranian Journal of Language Teaching Research, Vol. 4, No. 3, pp. 2136 (2016)

[15] Debreli, E.: Pre-Service teachers' belief change and practical knowledge development during the course of practicum. Journal of Education and Training Studies, Vol. 4, No. 7, pp. 37-46 (2006)

[16] Narváez, N. C. D., Ramírez, S. P. L., \& Vasco, A. M. M.: Beliefs of pre-service teachers about English language teaching: reflection and practice. FOLIOS, Vol. 45, pp. 177-193 (2017)

[17] Holt-Reynolds, D.: Personal history-based beliefs as relevant prior knowledge in course work. American Educational Research Journal, Vol. 29, No. 2, pp. 325-349 (1992)

[18] de Vries, S., Jansen, E. P. W. W. A., Helms-Lorenz, M. \& van de Grift, W. J. C. M.: Student teachers' beliefs about learning and teaching and their perception in career-long learning activities. Journal of Education for Teaching, Vol. 40, No. 4, pp. 344-358 (2014)

[19] Larenas, C. D., Hernandez, P. A., \& Navarrete, M. O.: A case study on EFL teachers' beliefs about the teaching and learning of English in public education. Porta Linguarum, Vol. 23, pp. 171-186 (2015) [20] Sheridan, L.: Examining changes in pre-service teachers' beliefs of pedagogy. Australian Journal of Teacher Education, Vol. 41, No. 3, pp. 1-20 (2016)

[21] Akbari, Z.: Current challenges in teaching/learning English for EFL learners: the case of junior high school and high school. Procedia-Social and Behavioral Sciences, Vol. 199, No. 394-401 (2015)

[22] Goldfus, C.: The challenges facing the foreign language teacher education: a proposed teacher education model for EFL. Journal of NELTA, Vol. 16, pp. 1-2, 1-12 (2011)

[23] Bajrami, L.: Teacher's new role in language learning and in promoting learner autonomy. Procedia-Social and Behavioral Sciences, Vol. 199, pp. 423-427 (2015) 
[24] White, C.: The role of the teacher. Journal of Education for Teaching, Vol. 31, No. 4, pp. 269-271 (2005)

[25] Madalińska-Michalak, J., \& Bavli, B.: Challenges in teaching English as a foreign language at schools in Poland and Turkey. European Journal of Teacher Education, Vol. 41, No. 5, pp. 688-706 (2018)

[26] Tudor, I.: Teacher roles in the learner-centred classroom. ELT Journal, Vol. 47, No. 1, pp. 22-31 (1993)

[27] Gbollie, C., \& Keamu, H. P.: Student academic performance: the role of motivation, strategies, and perceived factors hindering Liberian junior and senior high school students learning. Education Research International, pp. 1-11 (2017)

[28] Krieger, D.: Teaching ESL versus EFL: principles and practices. English teaching forum, Vol. 43, No. 2 (2005)

[29] Alsubaie, M. A.: Curriculum development: teacher involvement in curriculum development. Journal of Education and Practice, Vol. 7, No. 9, pp. 106-107 (2016)

[30] Olatunji, M. O.: The affective domain of assessment in colleges and universities: issues and implications. International Journal of Progressive Education, Vol. 10, No. 1, pp. 101-116 (2014)

[31] Sönmez, V.: Association of cognitive, affective, psychomotor and intuitive domains in education, sönmez model. Universal Journal of Educational Research, Vol. 5, No. 3, pp. 347-356 (2017)

[32] Cheng, J.: Learning to attend to precision: the impact of micro-teaching guided by expert secondary mathematics teachers on pre-service teachers' training practice. Springer (2017) 